\title{
Avirulent Viable But Non Culturable cells of Listeria monocytogenes need the presence of an embryo to be recovered in egg yolk and regain virulence after recovery
}

\author{
Jean Michel CAPPELIER ${ }^{a *}$, Valérie BESNARD ${ }^{\mathrm{a}}$, Sylvie M. RochE ${ }^{\mathrm{b}}$, \\ Philippe VELGE ${ }^{\mathrm{b}}$, Michel FEDERIGHI ${ }^{\mathrm{a}}$ \\ ${ }^{a}$ Unité Mixte de Recherche INRA 1014 SECALIM, ENVN/ENITIAA, École Nationale Vétérinaire \\ de Nantes, BP 40706, Route de Gachet, 44307 Nantes, France \\ ${ }^{\mathrm{b}}$ Institut National de la Recherche Agronomique, Laboratoire d'Infectiologie Animale et Santé \\ Publique, 37380 Nouzilly, France
}

(Received 1 August 2006; accepted 30 January 2007)

\begin{abstract}
The aim of this study was to assess the efficiency of the embryonated egg model to recover Viable But Non Culturable (VBNC) cells of Listeria monocytogenes. L. monocytogenes cells were incubated in filtered sterilised distilled water. The VBNC state was obtained after a 25 to 47 days incubation period (concentration of culturable cells less than $1 \mathrm{cfu} / \mathrm{mL}$ ). Fifteen days after the VBNC state was reached, non culturability was checked in various media. One milliliter of each VBNC suspension that contained $10^{4}$ metabolically active cells (i.e. Direct Viable Count + cells) was inoculated into the vitellus fluid of embryonated and non-embryonated eggs. Culturable cells were detected in a large proportion of the embryonated eggs (18/32), but not in the non-embryonated eggs $(1 / 32)$. The recovery rate was higher after culture of the vitellus fluid plus embryo (18/32) than after culture of the vitellus fluid alone (6/32). The results indicate that the embryo likely plays a prominent part in the recovery process. The virulence of recovered cells was assessed by the ability to form plaques in HT-29 cell monolayers and by the ability to colonise mouse spleens. Although the cells were classified as avirulent when in the VBNC state, the virulence was recovered after resuscitation.
\end{abstract}

VBNC / virulence / embryonated eggs / Listeria monocytogenes

\section{INTRODUCTION}

Many bacteria have been shown to enter a Viable But Non Culturable (VBNC) state, in response to environmental stress. In this state, bacteria may no longer grow

* Corresponding author: cappelier@vet-nantes.fr on conventional culture media, but retain metabolic activity. The VBNC state has been described in major human pathogens, including Salmonella enteritidis [43], Vibrio cholerae [51], Vibrio vulnificus [28,34], Campylobacter jejuni [41], Legionella pneumophila [21], enterotoxigenic Escherichia coli [20], Shigella dysentariae [22] and recently Listeria 
monocytogenes [3]. The metabolic activity of VBNC bacteria has been tested by several cellular tests: incorporation of radio labelled substrate [41], Direct Viable Count (DVC) [27], double staining CTC/DAPI [40]. All these experiments have demonstrated the maintenance of cellular activity in part of the cell population having lost culturable ability. The significance of the passage into a VBNC state is controversial. Is this VBNC state adaptation or debilitation [29]? Some authors consider VBNC bacteria as a degenerative form, leading to death, without any role in transmission routes of pathogens [31]. Others regard this state as a survival strategy, in response to adverse environmental conditions and consider that VBNC response can represent a genetically programmed physiological adaptation [39]. In addition, VBNC cells have been shown to be able to retain virulence $[16,30]$. All these experiments have led us to consider the VBNC state in pathogenic bacteria as a potential threat to public health. In almost all the VBNC virulence studies, the pathogenicity of VBNC cells was directly linked to recovery. A number of animal models have been tested by various authors with different efficiencies: mice [33], chicks [45], embryonated eggs [11, 14] and human volunteers [17]. In Listeria monocytogenes the VBNC condition has been recently described and is well documented $[3,5]$. This major pathogen was implicated in the last two decades in several food borne disease outbreaks with high death rates $[6,18]$. This bacterium is capable of adhering to cell membranes and of invading eukaryotic cells like intestinal or hepatic cells. Then, Listeria monocytogenes is able to multiply inside host cells, and to escape the immune response. The existence of the VBNC state in a foodborne pathogen like Listeria monocytogenes, which exhibits a high lethality rate, needs to be taken into account. For these reasons, the levels of virulence of
Listeria monocytogenes VBNC cells were assessed by in vitro and in vivo tests in Cappelier et al. [12]. In addition, the ability of such VBNC cells to recover a culturable state must be investigated. The aim of this study was to assess the efficiency of embryonated eggs and non embryonated eggs in the recovery of VBNC cells of Listeria monocytogenes and to determine their virulence potential in mice and in cellular models.

\section{MATERIALS AND METHODS}

\subsection{Bacterial strains and growth conditions}

The Listeria monocytogenes strains used are described in Table I. They were provided by the "Laboratoire d'Infectiologie Animale et Santé Publique" (INRA, Nouzilly, France). Strains were grown for $24 \mathrm{~h}$ at $37{ }^{\circ} \mathrm{C}$ on Plate Count Agar (Biokar, Beauvais, France) for each test. These strains were chosen because of their origin (clinical and food isolates) and because they were previously used in VBNC studies in which optimal conditions to induce the VBNC state were described [3, 5, 12]. Two subcultures were performed under similar conditions and then the cells were placed in filtered sterilised distilled water (microcosm water) in order to induce the VBNC state. Table I indicates for each strain used, the temperature of incubation in filtered sterilised distilled water, the time needed to reach a concentration of culturable cells less than $1 \mathrm{cfu} / \mathrm{mL}$, the active cell count (DVC) [4] and total cell count.

\subsection{Recovery}

Fifteen days after the VBNC state was reached (Tab. I), non culturability was 
Table I. Characteristics of different VBNC cellular suspensions inoculated in embryonated and non embryonated eggs [12].

\begin{tabular}{|c|c|c|c|c|}
\hline \multirow[t]{2}{*}{ Strains } & \multicolumn{2}{|c|}{$\begin{array}{l}\text { Incubation conditions in distilled } \\
\text { sterilised filtered water }\end{array}$} & \multicolumn{2}{|c|}{$\begin{array}{l}\text { Concentration of suspensions at } \\
\text { inoculation time }{ }^{\mathrm{a}}\left(\text { cells } / \mathrm{mL} \pm \mathrm{SD}^{*}\right)\end{array}$} \\
\hline & $\begin{array}{l}\text { Temperature } \\
\left({ }^{\circ} \mathrm{C}\right)\end{array}$ & $\begin{array}{c}\text { Time }^{\mathrm{b}} \pm \mathrm{SD}^{\mathrm{c}} \\
(\text { days })\end{array}$ & $\begin{array}{l}\text { Active cells count } \\
{\text { (DVC })^{\mathrm{d}}}\end{array}$ & $\begin{array}{l}\text { Total cells count } \\
\text { (DAPI) }\end{array}$ \\
\hline CNL 895807 & 20 & $25 \pm 4$ & $4.3310^{4} \pm 0.35$ & $6.110^{6} \pm 0.4$ \\
\hline LO 28 & 20 & $27 \pm 3$ & $4.2210^{4} \pm 0.3$ & $6.210^{6} \pm 0.4$ \\
\hline ATCC 19115 & 20 & $24 \pm 3$ & $4.410^{4} \pm 0.4$ & $6.110^{6} \pm 0.3$ \\
\hline Scott A & 4 & $47 \pm 4$ & $4.110^{4} \pm 0.4$ & $6.210^{6} \pm 0.4$ \\
\hline
\end{tabular}

${ }^{a}$ The initial suspensions in filtered sterilised distilled water were almost $10^{6} \mathrm{cfu} / \mathrm{mL}$.

b Time necessary (days) to lose culturable state. At this time, culturable cells were $<1 \mathrm{cfu} / \mathrm{mL}$, metabolically active cells were almost $10^{4}$ cells $/ \mathrm{mL}$ and total cells were almost $10^{6}$ cells $/ \mathrm{mL}$ and no resuscitation was observed by traditional resuscitation techniques. Inoculation in eggs were done 15 days after this time.

${ }^{\mathrm{c}}$ SD: Standard Deviation.

${ }^{\mathrm{d}}$ DVC: Direct Viable Count.

checked after incubation of 24 to $72 \mathrm{~h}$ in various media (BHI, peptone, water, Minimum Essential Medium, Fetal Calf Serum) [12]. Then, $1 \mathrm{~mL}$ from each of the microcosm water samples was inoculated into embryonated eggs and into non embryonated eggs. Seven-day-old embryonated eggs from specific pathogen free chickens were purchased from Avibocage (Saint-Père-en-Retz, France). Nonembryonated eggs were purchased from a retailer. After disinfection of the egg shells (ethanol $70 \%$ ), a hole was made with a sterile needle $(0.9 / 40 \mathrm{~mm})$ on the opposite side of the air chamber. Then, $1 \mathrm{~mL}$ of each Listeria monocytogenes suspension was injected into the yolk sac of embryonated and non-embryonated eggs with a $1 \mathrm{~mL}$ syringe (needle dimensions: 0.9/40 mm). Negative control eggs were inoculated with $1 \mathrm{~mL}$ of sterilised distilled water. Immediately after inoculation, the opening in the shell was obstructed with wax (CML, Nemours, France) and the eggs were incubated at $37^{\circ} \mathrm{C}$. After incubation for 2 and 6 days, the egg shells were carefully broken. A volume of $0.2 \mathrm{~mL}$ of the vitellus fluid was harvested with a syringe and spread on 2 Petri dishes of Palcam agar (Merk, Darnstadt, Germany) and PCA (Biokar, Beauvais, France). These plates were incubated $48 \mathrm{~h}$ at $37^{\circ} \mathrm{C}$. For the embryonated eggs, the rest of the vitellus fluid and the embryo were removed and pounded in a stomacher for $1 \mathrm{~min}$. A volume of $0.2 \mathrm{~mL}$ of this mixture was spread on two Petri dishes of Palcam agar and PCA and incubated $48 \mathrm{~h}$ at $37^{\circ} \mathrm{C}$.

\subsection{Virulence tests}

The virulence tests were described in Cappelier et al. [12]. Briefly, the Listeria monocytogenes strains (culturable, VBNC and recovered cells) were tested with HT-29 cell monolayers in a plaqueforming assay $[48,49]$ and the strains were also tested for their potential to colonise mouse spleens (Swiss female OF1) after intravenous inoculation $[1,8]$ according to the methods described by Roche 
Table II. Virulence of culturable cells and VBNC cells of Listeria monocytogenes used in this study assessed by in vitro and in vivo assays [12].

\begin{tabular}{|c|c|c|c|c|c|c|}
\hline \multirow[t]{3}{*}{ Strains } & \multicolumn{2}{|c|}{$\begin{array}{l}\text { In vitro virulence assays } \\
\text { Plaque forming assay } \\
\text { Mean }(\log \pm \mathrm{SD})\end{array}$} & \multicolumn{4}{|c|}{$\begin{array}{l}\text { In vivo virulence assays } \\
\text { Intravenous test (spleens) }^{\mathrm{c}}\end{array}$} \\
\hline & \multirow[t]{2}{*}{ Culturable cells } & \multirow[t]{2}{*}{$\overline{\text { VBNC cells }}$} & \multicolumn{2}{|c|}{ Culturable cells } & \multicolumn{2}{|c|}{ VBNC cells } \\
\hline & & & $\begin{array}{c}\text { Mean } \\
(\log \pm \mathrm{SD})\end{array}$ & $\begin{array}{c}\text { Number of } \\
\text { positive cultures }^{\mathrm{d}}\end{array}$ & $\begin{array}{c}\text { Mean } \\
(\log \pm \mathrm{SD})\end{array}$ & $\begin{array}{c}\text { Number of } \\
\text { positive cultures }^{\mathrm{d}}\end{array}$ \\
\hline ATCC 19115 & $6.59 \pm 0.04$ & $0^{\mathrm{b}}$ & $5.31 \pm 0.15$ & $5 / 5$ & $0^{\mathrm{b}}$ & $0 / 5$ \\
\hline LO 28 & $5.56 \pm 0.06$ & $0^{\mathrm{b}}$ & $5.86 \pm 0.04$ & $5 / 5$ & $0^{\mathrm{b}}$ & $0 / 5$ \\
\hline Scott A & $6.55 \pm 0.3$ & $0^{\mathrm{b}}$ & $5.35 \pm 0.16$ & $5 / 5$ & $0^{\mathrm{b}}$ & $0 / 5$ \\
\hline CNL 895807 & $0^{\mathrm{b}}$ & $0^{\mathrm{b}}$ & $4.2 \pm 0.3$ & $5 / 5$ & $0^{\mathrm{b}}$ & $0 / 5$ \\
\hline Negative control $^{\mathrm{e}}$ & $0^{\mathrm{b}}$ & $0^{\mathrm{b}}$ & $0^{\mathrm{b}}$ & $0^{\mathrm{b}}$ & $0^{\mathrm{b}}$ & $0 / 5$ \\
\hline \multicolumn{7}{|c|}{$\begin{array}{l}\text { a Number of plaques for } 4 \log \text { cfu deposited. } \\
\text { b }<\text { limit of detection of the assay. } \\
\text { c Number of bacteria per spleen homogenate recovered in spleens } 2 \text { days after intravenous injection of } \\
\text { immuno-competent swiss mice with } 3 \log \text { cfu in } 100 \mu \mathrm{L} \text {. } \\
\text { d Number of mice with positive culture of Listeria monocytogenes in spleen / number of mice inoculate. } \\
\text { e Sterilised distilled water. }\end{array}$} \\
\hline
\end{tabular}

et al. [42]. The level of virulence determined by in vitro (PFA assay) and in vitro (inoculation in mice) techniques, for each strain used, in the culturable state and in the VBNC state were previously described in Cappelier et al. [12] (Tab. II). The VBNC cells of Listeria monocytogenes were unable to colonise the spleen after intraveinous inoculation. In the PFA assay, no plaques were observed for any VBNC cells.

\subsection{Identification of recovered strains}

To confirm that the strains recovered were the same as those inoculated, Listeria monocytogenes cells were submitted to restriction enzyme analysis with the restriction enzyme ApaI (Boehringer, Germany) and CHEF DRIII pulsed field gel electrophoresis (Biorad, Ivry-sur-Seine, France) [7].

\section{RESULTS}

\subsection{Comparison of recovery rate in embryonated and non embryonated eggs}

Table III shows the number of embryonated eggs from which Listeria monocytogenes culturable cells were isolated after inoculation with VBNC suspensions. The results of restriction enzyme analysis presented in Figure 1 ensure that recovered strains were the same as inoculated strains. Culturable Listeria monocytogenes cells were recovered from 6 out of $32 \mathrm{em}$ bryonated eggs when the culture was made of vitellus fluid only. All the recovered cells came from the eggs inoculated with strain Scott A. When culture was made from the vitellus fluid and embryo, recovered cells were isolated from 18 out of 32 eggs. For three strains (CNL 895807, LO 28 and ATCC 19115) the recovery rate (number of eggs colonised/number of 
Table III. Number of eggs (embryonated and non embryonated) colonised by Listeria monocytogenes, after inoculation with VBNC cell suspensions.

\begin{tabular}{|c|c|c|c|c|}
\hline \multirow[t]{3}{*}{ Strains } & \multirow[t]{3}{*}{ Incubation time ${ }^{\mathrm{a}}$ (days) } & \multicolumn{3}{|c|}{ No. of eggs colonised / no. of eggs inoculated } \\
\hline & & \multicolumn{2}{|c|}{ Inoculation in embryonated eggs } & \multirow{2}{*}{$\begin{array}{l}\text { Inoculation in non } \\
\text { embryonated eggs }\end{array}$} \\
\hline & & $\begin{array}{l}\text { Vitellus } \\
\text { fluid }^{\text {b }}\end{array}$ & $\begin{array}{l}\text { Vitellus fluid } \\
\text { and embryo }\end{array}$ & \\
\hline \multirow[t]{2}{*}{ ATCC 19115} & 2 & $0 / 4$ & $2 / 4$ & $0 / 4$ \\
\hline & 6 & $0 / 4$ & $2 / 4$ & $1 / 4$ \\
\hline \multirow[t]{2}{*}{ LO 28} & 2 & $0 / 4$ & $2 / 4$ & $0 / 4$ \\
\hline & 6 & $0 / 4$ & $2 / 4$ & $0 / 4$ \\
\hline \multirow[t]{2}{*}{ Scott A } & 2 & $2 / 4$ & $2 / 4$ & $0 / 4$ \\
\hline & 6 & $4 / 4$ & $4 / 4$ & $0 / 4$ \\
\hline \multirow[t]{2}{*}{ CNL 895807} & 2 & $0 / 4$ & $2 / 4$ & $0 / 4$ \\
\hline & 6 & $0 / 4$ & $2 / 4$ & $0 / 4$ \\
\hline Total & & $6 / 32$ & $18 / 32$ & $1 / 32$ \\
\hline \multirow[t]{2}{*}{ Negative control $^{\mathrm{d}}$} & 2 & $0 / 2$ & $0 / 2$ & $0 / 2$ \\
\hline & 6 & $0 / 2$ & $0 / 2$ & $0 / 2$ \\
\hline
\end{tabular}

${ }^{\text {a }}$ Incubation time of eggs inoculated at $37^{\circ} \mathrm{C}$.

${ }^{\mathrm{b}}$ Only the vitellus fluid was cultured.

${ }^{c}$ The vitellus fluid and the embryo were cultured.

${ }^{\mathrm{d}}$ Sterilised distilled water.

eggs inoculated) was $50 \%$, but higher for strain Scott A (6/8). After passage in nonembryonated eggs, no recovery was obtained after two days of incubation. Only one egg inoculated with ATCC 19115 strain showed recovery after a six day incubation period.

So, the probability to obtain recovery of VBNC cells of Listeria monocytogenes was higher after an embryonated egg passage than after a non embryonated egg passage. For the embryonated egg passages, the recovery rate was higher when the culture was made of vitellus fluid and embryo than when it was only made of vitellus fluid, except for strain Scott A that behaved identically in both conditions.

\subsection{Virulence tests}

Virulence was determined by in vitro (PFA assay) and in vivo (inoculation in mice) techniques, for each strain after recovery in embryonated eggs. The results are presented in Table IV. The loss of pathogenicity of these VBNC cells was transient, since after an embryonated egg passage, the virulence of recovered cells was identical to that of culturable cells.

\section{DISCUSSION}

The results presented in this study show that VBNC cells of Listeria monocytogenes could be recovered after an embryonated egg passage. It has been established that VBNC Listeria monocytogenes cells are unable to grow in conventional culture media and cannot be resuscitated by traditional reviving techniques $[3,5]$. For the four strains inoculated in filtered sterilised distilled water at the initial concentration of $10^{6}$ cells $/ \mathrm{mL}$, the active cell count was almost $10^{4}$ cells $/ \mathrm{mL}$ and the culturable cell count was below 


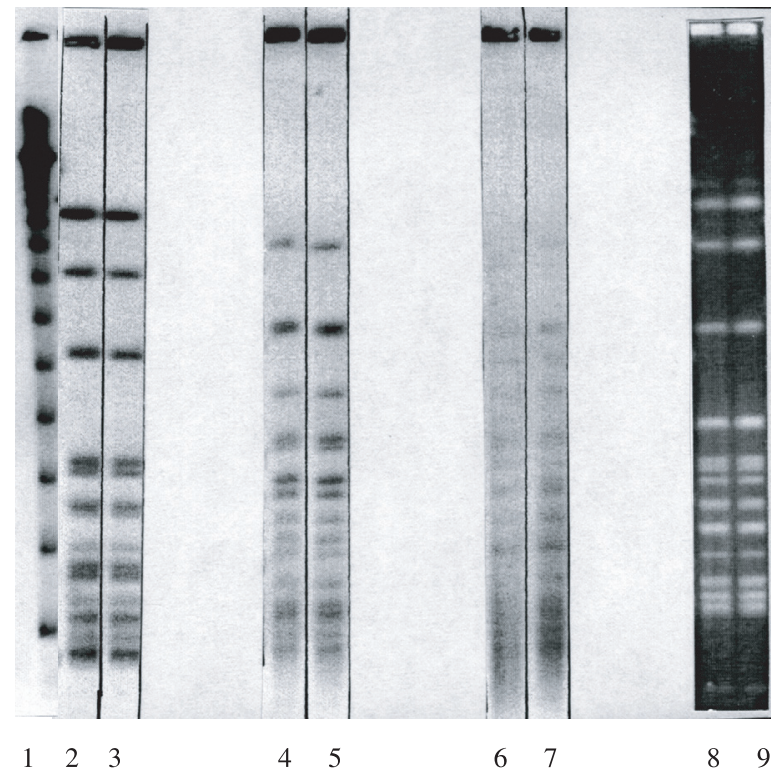

Figure 1. Restriction enzyme analysis of Listeria monocytogenes: 1: Lambda ladder marker; 2: Positive control for strain CNL 895807; 3: Strain CNL 895807 recovered after an embryonated egg passage; 4: Positive control for strain Scott A; 5: Strain Scott A recovered after an embryonated egg passage; 6: Positive control for strain ATCC 19115; 7: Strain ATCC 19115 recovered after an embryonated egg passage; 8: Positive control for strain LO 28; 9: Strain LO 28 recovered after an embryonated egg passage.

Table IV. Virulence of recovered cells of Listeria monocytogenes after embryonated egg passage assessed by in vitro and in vivo assays.

\begin{tabular}{lccc}
\hline Strains & $\begin{array}{c}\text { In vitro virulence assays } \\
\text { Plaque forming assay }\end{array}$ & \multicolumn{2}{c}{$\begin{array}{c}\text { In vivo virulence assays } \\
\text { Intravenous test }(\text { spleens })^{\mathrm{b}}\end{array}$} \\
\cline { 3 - 4 } & Mean $(\log \pm \mathrm{SD})$ & Mean $(\log \pm \mathrm{SD})$ & ${\text { Number of positive } \text { cultures }^{\mathrm{c}}}$ \\
\hline ATCC 19115 & $6.15 \pm 0.05$ & $5.51 \pm 0.51$ & $5 / 5$ \\
LO 28 & $5.88 \pm 0.04$ & $5.39 \pm 0.49$ & $5 / 5$ \\
Scott A & $6.46 \pm 0.13$ & $5.23 \pm 0.49$ & $5 / 5$ \\
CNL 895807 & $0^{\mathrm{e}}$ & $4.05 \pm 0.27$ & $5 / 5$ \\
Negative control $^{\mathrm{d}}$ & $0^{\mathrm{e}}$ & $0^{\mathrm{e}}$ & $0 / 5$ \\
\hline
\end{tabular}

${ }^{\text {a }}$ Number of plaques for $4 \log$ cfu deposited.

${ }^{b}$ Number of bacteria per spleen homogenate recovered in spleens 2 days after intravenous injection of immuno-competent swiss mice with $3 \log$ cfu in $100 \mu \mathrm{L}$.

${ }^{\mathrm{c}}$ Number of mice with positive culture of Listeria monocytogenes in spleen / number of mice inoculate.

${ }^{\mathrm{d}}$ Sterilised distilled water.

e $<$ limit of detection of the assay. 
$1 \mathrm{cfu} / \mathrm{mL}$ at the time of the recovery experiment. The recovery rates (number of eggs colonised/number of eggs inoculated) obtained ranged between $3.1 \%$ and $56.2 \%$ according to the model used (non embryonated eggs, embryonated eggs with culture of vitellus fluid alone, embryonated eggs with culture of both vitellus fluid and embryo). Recovery of VBNC cells of various enteropathogens has already been described. Restoration of such cells was investigated either in in vitro or in vivo experiments, but only few recoveries were obtained by the in vivo experiments. These ones looked like reviving techniques. Roszak et al. [43] were the first to report the recovery of VBNC cells. Non culturable cells of Salmonella enteritis were obtained by incubation in sterile water. Recovery was observed after supplementation with nutrients (BHI infusion), but only occurred four days after entry of the cells in the VBNC state, and not after an extended period. So, the authors concluded that reviving VBNC cells under prolonged starvation requires additional factors. Roth et al. [44] succeeded in reviving VBNC cells of Escherichia coli obtained by osmotic shock. Eighty percent of the cells became culturable after addition of betaine. Recovery occurred in the presence of chloramphenicol. So, the authors demonstrated that the recovery did not result from the multiplication of a few cells remaining culturable. Wai et al. [50] described resuscitation of VBNC cells of Aeromonas hydrophila by culture on media supplemented with $\mathrm{H}_{2} \mathrm{O}_{2}$ degrading agents, catalase and sodium pyruvate. In vivo recovery was also observed in Vibrio by increasing temperature $[33,34]$. Other authors estimated that this recovery was probably the consequence of a rapid multiplication of undetected cells remaining culturable $[23,38]$. VBNC cells of various pathogens have also been recovered in animal models: mice for $\mathrm{Vib}$ rio vulnificus [35] and Campylobacter je- juni [10, 24]; rat gut for Campylobacter jejuni [45]; chicks for Campylobacter jejuni $[10,46]$; rabbit ileal loop for Vibrio cholerae [15]; human volunteers for Vibrio cholerae [15] and fertilised eggs for Legionella pneumophilla [21] and Campylobacter jejuni $[11,14]$. For this species, it appears that inoculation of VBNC cells in the yolk sac of embryonated eggs was the best way to obtain recovery at a culturable state $[11,14,47]$. In contrast, Medema et al. [31] did not succeed in recovering VBNC cells of Campylobacter jejuni after inoculation in fertilised eggs. In this experiment, VBNC cell suspensions were inoculated into the allantoïc cavity, where the $\mathrm{pH}$ and the presence of antimicrobial substances were not favourable to bacterial growth. These findings allow speculation on the factors responsible for the recovery of VBNC cells, which are likely located in the vitellus fluid or in the embryo, rather than in the allantoïc fluid.

As far as we know, this experiment represents the first demonstration of recovery of VBNC cells of Listeria monocytogenes. It confirms the efficacy of the embryonated egg model as described in previous works in Campylobacter jejuni VBNC cells [10, 13, 47]. Moreover, two important findings described in this work need to be taken into account. First, embryonated eggs allow better recovery than non embryonated eggs. In addition, recovery was improved in the presence of the embryo: better results were obtained after culture of the vitellus fluid and embryo, when VBNC cells were inoculated in embryonated eggs, whereas the recovery rate significantly decreased when VBNC cells were inoculated in non embryonated eggs. So, according to the present results, the substance that allows recovery seems to be located in the chick embryo. Such recovery factors have already been described as bacterial cytokines [26, 32]. These authors have demonstrated the existence of a resuscitation promoting factor 
(RPF), which was shown to increase the viable cell count of dormant Micrococcus luteus cultures and also to stimulate the growth of other bacteria. Kaprelyants and Kell [25] presented a variety of eukaryotic hormones, which have been shown to stimulate bacterial growth. Recently, Chemaly and Salvat ${ }^{1}$ suggested that the ion-protein complex of the embryonated eggs, which protects against oxidative stress, could be involved in the recovery process of VBNC cells.

It has been previously described that entry into a VBNC state is accompanied by a loss of pathogenicity of Listeria monocytogenes [12]. VBNC cells of Listeria monocytogenes were not able to colonise the spleen of mice, and did not adhere to HT 29 cells. So, these cells can be regarded as avirulent. But, we showed here that this virulence loss was transient since, after an embryonated egg passage, the pathogenic effect was restored at a level identical to the initial one. Such a transient loss of pathogenicity has already been described for Campylobacter jejuni $[11,45]$. The virulence signals (accumulation of fluid in the gut or attachment index on HeLa cells) decreased in the VBNC state and increased to the baseline level after recovery. However, some experiments have shown that VBNC cells retain pathogenic effects. Oliver and Bockian [36] observed a lethal effect in mice inoculated with VBNC cells of Vibrio vulnificus. Other works established that Escherichia coli VBNC cells kept their pathogenicity by keeping the ability to produce little amounts of enterotoxin $[2,37]$ or by preserving plasmids involved in pathogenicity [9]. Chaiyanan et al. showed conservation of cholera toxin and toxinassociated genes in VBNC cells of Vibrio

\footnotetext{
${ }^{1}$ Chemaly Z., Salvat G., Physiologie de la revivification des formes viables non cultivables chez Campylobacter jejuni, 6th national congress, Société Française de Microbiologie, 2004, Bordeaux.
}

cholerae [13]. It seems difficult to know if such pathogenic effects were due to VBNC cells or to cells that reverted to a culturable state. But, recently, Fischer-Le Saux et al. [19] detected a cytotoxin-hemolysin mRNA produced by a non culturable population of Vibrio vulnificus. They concluded that special attention should be given to the presence of potentially pathogenic VBNC cells in environmental samples when assessing public health risk. In the present work, the virulence of VBNC cells of Listeria monocytogenes seems to be indissoluble from the ability to grow and need to return to a culturable state to express itself.

Even if some of the results of the VBNC experiments published are sometimes conflicting, and if the demonstration of the presence of VBNC cells in foods other than water has not yet been made, the VBNC state of food bacterial pathogens must be taken into consideration, because classical microbiological methods do not allow detection of such potentially pathogenic bacteria. The solution would be to create a specific culture medium making it possible to recover VBNC cells. For that, further studies are needed to identify one or several factors involved in the switch from a non culturable to a culturable state.

\section{REFERENCES}

[1] Audurier A., Pardon P., Marly J., Lantier F., Experimental infection of mice with Listeria monocytogenes and Listeria innocua, Ann. Microbiol. (Paris) (1980) 131B:47-57.

[2] Barcina I., Gonzalez J.M., Iriberri J., Egea L., Survival strategy of Escherichia coli and Enterococcus faecalis in illuminated fresh and marine system, J. Appl. Bacteriol. (1990) 68:189-198.

[3] Besnard V., Federighi M., Cappelier J.M., Evidence of VBNC state in Listeria monocytogenes by DVC and CTC-DAPI double staining, Food Microbiol. (2000) 17:697-704.

[4] Besnard V., Federighi M., Cappelier J.M., Development of a direct viable count 
procedure for the investigation of VBNC state in Listeria monocytogenes, Lett. Appl. Microbiol. (2000) 30:1-6.

[5] Besnard V., Federighi M., Declerq E., Jugiau F., Cappelier J.M., Environmental and physico-chemical factors induce VBNC state in Listeria monocytogenes, Vet. Res. (2002) 33:359-370.

[6] Bhunia A.K., Antibodies to Listeria monocytogenes, Crit. Rev. Microbiol. (1997) 23:77-107.

[7] Brosch R., Burchrieser C., Rocourt J., Subtyping of Listeria monocytogenes serovar $4 \mathrm{~b}$ by use of low frequency cleavage restriction endonucleases and pulsed field electrophoresis, Res. Microbiol. (1991) 142:667-675.

[8] Brosch R., Catimel B., Milon G., Buchrieser C., Vindel E., Rocourt J., Virulence heterogeneity of Listeria monocytogenes strains from various sources (food, human, animal) in immunocompetent mice and its association with typing characteristics, J. Food Prot. (1993) 56:296-301.

[9] Byrd J.J., Colwell R.R., Maintenance of plasmids pBR322 and pUC8 in nonculturable Escherichia coli in the marine environment, Appl. Environ. Microbiol. (1990) 56:2104-2107.

[10] Cappelier J.M., Magras C., Jouve J.L., Federighi M., Recovery of viable but non-culturable Campylobacter jejuni cells in two models, Food Microbiol. (1999) $16: 375-383$.

[11] Cappelier J.M., Minet J., Magras C., Colwell R.R., Federighi M., Viable but non culturable Campylobacter jejuni cells recover culturability and adhesion abilities after embryonated egg passage, Appl. Environ. Microbiol. (1999) 65:5154-5157.

[12] Cappelier J.M., Besnard V., Roche S., Garrec N., Zundel E., Velge P., Federighi M., Avirulence of Viable But Non Culturable Listeria monocytogenes cells demonstrated by in vitro and in vivo models, Vet. Res. (2005) 36:589-599.

[13] Chaiyanan S., Chaiyanan S., Huq A., Maugel T., Colwell R.R., Viability of the nonculturable Vibrio cholerae O1 and O139, Syst. Appl. Microbiol. (2001) 24:331-341.

[14] Chaveerach P., ter Huurne A.A.H.M., Lipman L.J.A, van Knapen F., Survival and resuscitation of ten strains of Campylobacter jejuni and Campylobacter coli under acid conditions, Appl. Environ. Microbiol. (2003) 69:711-714.

[15] Colwell R.R., Brayton P.R., Grimes D.J., Roszak D.B., Hug S.A., Palmer L.M., Viable but non culturable Vibrio cholearae and related pathogens in the environment: implication for release of genetically engineered microorganisms, Biotechnology (1985) 3:817-820.

[16] Colwell R.R., Tamplin M.L., Brayton P.R., Gauzens A.L., Tall B.D., Herrington D., Levine M.M., Hall S., Huq A., Sack D.A., Environmental aspects of Vibrio cholerae in transmission of cholera, in: Sack R.B., Zinnaka Y. (Eds.), Advances on cholera and related diarrheas, 7th edition, KTK Scientific, Tokyo, 1990, pp. 327-343.

[17] Colwell R.R., Brayton P., Herrington D., Tall B., Huq A., Levine M.M., Viable but nonculturable Vibrio cholerae 01 revert to a cultivable state in the human intestine, World J. Microbiol. Biotechnol. (1996) 12:28-31.

[18] Farber J.M., Peterkin P.I., Listeria monocytogenes, a food-borne pathogen, Microbiol. Rev. (1991) 55:476-511.

[19] Fischer-Le Saux M., Hervio-Health D., Loaec S., Colwell R.R., Pommepuy M., Detection of cytotoxin-hemolysin mRNA in non culturable populations of environmental and clinical Vibrio vulnificus strains in artificial seawater, Appl. Env. Microbiol. (2002) 68:5641-5646.

[20] Flint K.P., The long-term survival of Escherichia coli in river water, J. Appl. Bacteriol. (1987) 63:261-270.

[21] Hussong D., Colwell R.R., O’Brien M., Weiss E., Pearson A.D., Weimer R.M., Burge W.D., Viable Legionella pneumophila not detectable by culture on agar media, Biotechnology (1987) 5:947-950.

[22] Islam M.S., Hasan M.K., Miah M.A., Sur G.C., Felsentein A., Venkatesan M., Sack R.B., Albert M.J., Use of the polymerase chain reaction and fluorescentantibody methods for detecting viable but nonculturable Shigella dysentariae type 1 in laboratory microcosms, Appl. Environ. Microbiol. (1993) 59:536-539.

[23] Jiang X., Chai T.J., Survival of Vibrio parahaemolitycus at low temperatures under 
starvation conditions and subsequent resuscitation of viable, nonculturable cells, Appl. Environ. Microbiol. (1996) 62:1300-1305.

[24] Jones D.M., Sutcliffe E.M., Curry A., Recovery of viable but nonculturable Campylobacter jejuni, J. Gen. Microbiol. (1991) 137:2477-2482.

[25] Kaprelyants A.S., Kell D.B., Do bacteria need to communicate with each other for growth, Trends Microbiol. (1996) 4:237-242.

[26] Kell D.B., Young M., Bacterial dormancy and culturability: the role of autocrine growth factors, Curr. Opin. Microbiol. (2000) 3:238-243.

[27] Kogure K., Simidu U., Taga N., A tentative direct microscopic method for counting living marine bacteria, Can. J. Microbiol. (1979) 25:415-420.

[28] Linder K., Oliver J.D., Membrane fatty acid and virulence changes in the viable but nonculturable state of Vibrio vulnificus, Appl. Environ. Microbiol. (1989) 55:2837-2842.

[29] Mc Douglad D., Rice S.A., Wiechart D., Kjelleberg S., Non culturability: adaptation or debilitation? FEMS Microbiol. Ecol. (1998) 25:1-9.

[30] Mc Kay A.M., Viable but non-culturable forms of potentially pathogenic bacteria in water, Lett. Appl. Microbiol. (1992) 14:129-135.

[31] Medema G.J., Schets F.M., Van de Giessen A.W., Havelaar A., Lack of colonization of one day old chicks by viable, non-culturable Campylobacter jejuni, J. Appl. Bacteriol. (1992) 72:512-516.

[32] Mukamolova G.V., Kaprelyants A.S., Young D.I., Young M., Kell D.B., A bacterial cytokine, Proc. Natl. Acad. Sci. USA (1998) 95:8916-8921.

[33] Nilsson L., Oliver J.D., Kjelleberg S., Resuscitation of Vibrio vulnificus from the viable but nonculturable state, J. Bacteriol. (1991) 173:5054-5059.

[34] Oliver J.D., Wanucha D., Survival of Vibrio vulnificus at reduced temperatures and elevated nutrient, J. Food Saf. (1989) 10:79-86.

[35] Oliver J.D., Hite F., McDougald D., Andon N.L., Simpson L.M., Entry into, and resuscitation from, the viable but nonculturable state by Vibrio vulnificus in an Estuarine environment, Appl. Environ. Microbiol. (1995) 61:2624-2630.

[36] Oliver J.D., Bockian R., In vivo resuscitation and virulence towards mice of viable but nonculturable cells of Vibrio vulnificus, Appl. Environ. Microbiol. (1995) 61:2620-2623.

[37] Pommepuy M., Butin M., Derrien A., Gourmelon M., Colwell R.R., Cormier M., Retention of enteropathogenicity by viable but non culturable Escherichia coli exposed to seawater and sunlight, Appl. Environ. Microbiol. (1996) 62:4621-4626.

[38] Ravel J., Knight I.T., Monahan C.E., Hill R.T., Colwell R.R., Temperature-induces recovery of Vibrio cholerae from the viable but nonculturable state: growth or resuscitation? Microbiology (1995) 141:377-383.

[39] Rice S.A., McDouglad D., Kjelleberg S., Vibrio vulnificus: a physiological and genetic approach to the viable but nonculturable response, J. Infect. Chemother. (2000) 6:115-120.

[40] Rodriguez G.G., Phipps D., Ishiguro K., Ridgway H.F., Use of a fluorescent redox probe for direct visualization of actively respiring bacteria, Appl. Environ. Microbiol. (1992) 58:1801-1808.

[41] Rollins D.M., Colwell R.R., Viable but nonculturable stage of Campylobacter jejuni and its role in survival in the natural aquatic environment, Appl. Environ. Microbiol. (1986) 52:531-538.

[42] Roche S.M., Velge P., Bottreau E., Durier C., Marquet-van der Mee N., Pardon P., Assesment of the Listeria monocytogenes agreement between a aplaque forming assay with Ht-29 cells and infection of immunocompetent mice, Int. J. Food Microbiol. (2001) $68: 33-44$.

[43] Roszak D.B., Grimes D.J., Colwell R.R., Viable but nonrecoverable stage of Salmonella enteritidis in aquatic systems, Can. J. Microbiol. (1984) 334-338.

[44] Roth W.G., Leckie M.P., Dietzler D.N., Restoration of colony-forming activity in osmotically stressed Escherichia coli by betaine, Appl. Environ. Microbiol. (1988) 54:3142-3146.

[45] Saha S.K., Saha S., Sanyal S.C., Recovery of injured Campylobacter jejuni cells after 
animal passage, Appl. Environ. Microbiol. (1991) $57: 388-3389$.

[46] Stern N.J., Jones D.M., Wesley I.V., Rollins D.M., Colonization of chicks by nonculturable Campylobacter spp., Lett. Appl. Microbiol. (1994) 18:333-336.

[47] Talibart R., Denis M., Castillo A., Cappelier J.M., Ermel G., Survival and recovery of viable but noncultivable forms of Campylobacter in aqueous microcosm, Int. J. Food. Microbiol. (2000) 10:263-267.

[48] Van Langendonck N., Bottreau E., Bailly S., Tabouret M., Marly J., Pardon P., Velge P., Tissue culture assays using Caco- 2 cell line differentiate virulent from non-virulent Listeria monocytogenes strains, J. Appl. Microbiol. (1998) 85:337-342.
[49] Velge P., Bottreau E., Van lanfendonck N., Kaeffer B., Cell proliferation enhances entry of Listeria monocytogenes into intestinal epithelial cells by two proliferation-dependent entry pathways, J. Med. Microbiol. (1997) 46:681-692.

[50] Wai S.N., Mizunoe Y., Takade A., Yoshida S., A comparison of solid and liquid media for resuscitation of starvation and low temperature induced nonculturable cells of Aeromonas hydrophila, Arch. Microbiol. (2000) 173:307-310.

[51] Xu H.S., Robert N., Singleton F.L., Attwell R.W., Grimes D.J., Colwell R.R., Survival and viability of non culturable Escherichia coli and Vibrio cholerae in the estuarine and marine environment, Microb. Ecol. (1982) 8:313-323. 